\title{
PENGARUH PENYEMPROTAN EKSTRAK DAUN ALPUKAT DAN LARUTAN SODIUM HIPOKLORIT PADA CETAKAN ELASTOMER TERHADAP STABILITAS DIMENSI
}

\author{
Dwi Tjahyaning Putranti, Afrita Rizky \\ Departemen Prostodonsia Fakultas Kedokteran Gigi Universitas Sumatera Utara \\ Email: afrita.rizky@gmail.com
}

\begin{abstract}
Abstrak
Faktor utama keberhasilan perawatan jangka panjang prostodonsia adalah keakuratan dari gigi tiruan. Prosedur pencetakan merupakan salah satu tahap yang sangat penting dalam pembuatan gigi tiruan. Polivinil siloksan (PVS) adalah bahan cetak elastomer yang sering digunakan di kedokteran gigi untuk melakukan pencetakan. Berdasarkan anjuran American Dental Association (ADA) membersihkan darah dan saliva dari hasil cetakan menggunakan larutan desinfektan sebelum dilakukan pengisian gipsum di laboratorium sangatlah penting. Proses desinfeksi dapat dilakukan dengan menggunakan bahan kimia buatan maupun alami. Salah satu metode desinfeksi adalah metode penyemprotan, yang dapat mengurangi resiko perubahan stabilitas dimensi hasil cetakan. Penelitian ini bertujuan untuk mengetahui pengaruh penyemprotan ekstrak daun alpukat 25\% dan larutan sodium hipoklorit 0,5\% pada cetakan elastomer terhadap stabilitas dimensi. Rancangan penelitian ini adalah eksperimental laboratoris dengan sampel hasil cetakan elastomer yang telah diisi gips tipe IV diperoleh dari pencetakan pada model induk yang terbuat dari stainless steel berbentuk 2 mahkota yang telah dipreparasi dengan ukuran bukolingual 6,33 mm, oklusogingival 8,02 mm, dan interpreparasi 28,25 mm. Jumlah sampel 30 buah untuk 3 kelompok. Sampel diukur menggunakan kaliper digital kemudian dianalisis dengan uji t tidak berpasangan. Hasil penelitian ini menunjukkan bahwa ada pengaruh penyemprotan ekstrak daun alpukat 25\% dan larutan sodium hipoklorit 0,5\% pada cetakan elastomer terhadap stabilitas dimensi, namun perubahan yang terjadi dalam batas yang masih dapat di tolerir dengan persentase perubahan stabilitas dimensi $<0,5 \%$, tetapi tidak ada perbedaan pengaruh antara penyemprotan ekstrak daun alpukat 25\% dan larutan sodium hipoklorit 0,5\% pada cetakan elastomer terhadap stabilitas dimensi.
\end{abstract}

Kata kunci : Penyemprotan, ekstrak daun alpukat, sodium hipoklorit, elastomer, stabilitas dimensi

\section{PENDAHULUAN}

Kehilangan satu atau beberapa gigi dapat menyebabkan terjadinya perubahan jaringan di rongga mulut. Ketika gigi yang hilang tidak segera diganti hal ini dapat menimbulkan kesulitan bagi pasien sendiri, seperti mengunyah makanan, adanya gigi yang supraerupsi, miring atau bergeser. Penggantian gigi yang hilang pada umumnya dapat dilakukan dengan pembuatan gigi tiruan lepasan dan gigi tiruan cekat. ${ }^{1}$ Faktor utama keberhasilan perawatan jangka panjang prostodonsia adalah keakuratan dari gigi tiruan dan untuk menghindari kegagalan, seluruh prosedur klinis maupun laboratoris harus diikuti. Keberhasilan suatu gigi tiruan sangat tergantung pada proses pembuatannya. ${ }^{2}$

Prosedur pencetakan merupakan salah satu tahap yang sangat penting dalam pembuatan gigi tiruan sebagian lepasan, gigi tiruan penuh dan gigi tiruan cekat. Prosedur pencetakan dilakukan dengan menggunakan bahan cetak. ${ }^{3,4}$ Salah satu bahan cetak elastis yang sering digunakan untuk pembuatan model kerja di kedokteran gigi adalah bahan cetak elastomer. ${ }^{5}$ Menurut ADA (American Dental
Association) bahan cetak elastomer secara kimia dibagi menjadi empat jenis yaitu polisulfid, polieter, silikon kondensasi dan silikon adisi. ${ }^{6}$ Silikon adisi yang dikenal juga dengan sebutan polivinil siloksan (PVS) merupakan bahan cetak yang sangat akurat karena mampu menghasilkan cetakan dengan distorsi minimal sehingga dapat digunakan untuk mencetak pembuatan gigi tiruan cekat. ${ }^{7}$ Kekurangannya terletak pada harga dari PVS yang mahal dan sifatnya yang hidrofobik. Sifat yang hidrofobik menyebabkan saat penggunaan perlu diciptakan keadaan rongga mulut yang kering dan bebas dari air dan saliva. Hal tersebut sulit dilakukan sehingga seiring perkembangan, bahan ini telah dimodifikasi dengan menambahkan surfaktan untuk meningkatkan hidrophilicity bahan. ${ }^{8}$

Faktor lain yang harus diperhatikan saat menggunakan bahan cetak adalah kontrol dari penularan infeksi silang yang berasal dari hasil cetakan. ${ }^{9}$ Ketika dilakukan prosedur pengambilan cetakan, saliva dan darah dapat menempel pada hasil cetakan yang merupakan sumber kontaminasi dan memungkinkan berbagai mikroorganisme patogen dari rongga mulut dapat melekat 
pada cetakan tersebut. ${ }^{10}$ Salah satu studi menemukan bahwa $67 \%$ dari hasil cetakan yang dikirim dokter gigi ke laboratorium dental terkontaminasi oleh bakteri patogen. ${ }^{11}$ Terdapat beberapa bakteri yang dapat ditemukan pada hasil cetakan, diantaranya Streptococci (100\%), Staphylococci (65,4\%), dan $P$. aeruginosa (7,7\%). Semua bakteri tersebut bersifat patogen yang dapat mengakibatkan infeksi nasokomial dan membahayakan kesehatan bagi orang yang memiliki imunitas rendah. Menurut Miller dan Cottone setetes saliva mengandung 50.000 bakteri yang berpotensi patogen dan dapat dengan mudah menyebar melalui bahan cetak. ${ }^{12}$ Mikroorganisme dapat berinteraksi dengan bahan cetak dan menjadi agen penyebab infeksi sehingga menjadi pencetus penularan penyakit. Terdapat pedoman pengendalian infeksi dalam perawatan kesehatan gigi bahwa semua hasil cetakan harus dibersihkan, didesinfeksi dan dibilas menggunakan larutan desinfektan. ${ }^{9}$ Berdasarkan anjuran ADA membersihkan darah dan saliva dari hasil cetakan menggunakan larutan desinfektan sebelum dilakukan pengisian gipsum di laboratorium sangatlah penting. ${ }^{13}$ Metode desinfeksi yang digunakan dalam melakukan tindakan pencegahan infeksi silang pada cetakan adalah melalui metode perendaman dan penyemprotan. ${ }^{9,11}$ Pada proses desinfeksi dengan metode penyemprotan ADA merekomendasikan bahan cetak disemprot kemudian dimasukkan dalam kantong plastik sesuai dengan waktu yang direkomendasikan dan ADA juga merekomendasikan sepuluh menit perendaman dalam 1:10 pengenceran $(0,525 \%)$ dari larutan sodium hipoklorit. Metode penyemprotan dianggap sebagai metode yang efektif untuk mengurangi terjadinya resiko perubahan dimensi pada cetakan dibandingkan dengan teknik perendaman. $^{14}$

Desinfeksi bahan cetak menggunakan bahan kimia sangat dianjurkan. Desinfektan kimia buatan yang paling sering digunakan pada cetakan PVS adalah sodium hipoklorit karena memiliki beberapa keuntungan diantaranya bekerja cepat, mudah diperoleh serta mempunyai kemampuan antimikrobial spektrum luas. ${ }^{9}$ Penyemprotan menggunakan sodium hipoklorit 0,5\% terbukti efektif untuk mencegah infeksi silang yang disebabkan bakteri gram positif dan negatif. ${ }^{5}$ Menurut Merchant dkk (2004) larutan sodium hipoklorit dengan konsentrasi 0,5\% sudah cukup mendesinfeksi bahan cetak. $^{10}$ Berdasarkan penelitian Santosh (2011) dalam waktu 10 menit penyemprotan sodium hipoklorit 0,525\% terjadi penurunan jumlah bakteri pada bakteri jenis S.aureus, S.viridans dan B. subtilis yang terdapat pada cetakan. ${ }^{15}$

Bahan tradisional dari tanaman Indonesia juga sudah banyak digunakan sebagai desinfektan salah satunya daun alpukat. Daun alpukat menurut penelitian sebelumnya mengenai analisis fitokimia beberapa tumbuhan obat menunjukkan bahwa daun alpukat memiliki kandungan senyawa aktif antibakteri. ${ }^{16}$ Katja dkk (2009) menyatakan bahwa daun alpukat mengandung flavonoid, alkaloid, polifenol, tanin dan saponin yang mempunyai aktivitas antibakteri dan mampu menghambat pertumbuhan bakteri. ${ }^{17}$ Flavonoid, alkaloid, dan saponin termasuk senyawa fenol, dan banyak ditemukan pada tumbuhan. Dalam dunia kedokteran, senyawa fenol diketahui mempunyai efek antiseptik. ${ }^{18,19}$ Penelitian Fauzia dan Larasati (2008) menunjukkan konsentrasi 25\% ekstrak daun alpukat dapat menghambat pertumbuhan 1 kelompok Streptococcus mutans, dari 6 kelompok Streptococcus mutans yang diuji. ${ }^{18}$ Charyadie FL dkk (2014) yang meneliti efektivitas ekstrak daun alpukat terhadap pertumbuhan Enterococcus faecalis dengan beberapa konsentrasi menyatakan bahwa ekstrak daun alpukat dengan konsentrasi 25\% mempunyai daya hambat terhadap pertumbuhan Enterococcus faecalis. ${ }^{16}$

Penggunaan bahan desinfektan juga dapat berpengaruh terhadap perubahan stabilitas dimensi pada bahan cetak yang digunakan dalam kedokteran gigi. Stabilitas dimensi pada cetakan merupakan hal penting dalam keberhasilan pembuatan gigi tiruan. Pertimbangan yang harus tetap diperhatikan dalam memilih metode desinfeksi bahan cetak adalah pengaruh larutan desinfektan terhadap stabilitas dimensi dan efek mematikan bakteri. Lamanya desinfeksi pada bahan cetak juga dapat berpengaruh pada saat dilakukan desinfeksi., ${ }^{5,20}$ Efek pemakaian desinfektan pada stabilitas dimensi hasil cetakan sedang dipelajari secara luas. ${ }^{14}$ Menurut ketentuan spesifikasi ANSI/ADA, penelitian tentang bahan cetak elastomer termasuk stabilitas dimensinya dapat dilakukan dengan mengukur jarak bukolingual, oklusogingival, serta interpreparasi pada model yang dicetak dari model induk. Menurut spesifikasi ADA, perubahan stabilitas dimensi pada bahan cetak elastomer yang bisa ditolerir adalah $\leq 0,5 \%$. ${ }^{7,21}$ Ongo TA dkk (2014) menyatakan bahwa penggunaan teknik penyemprotan dengan sodium hipoklorit 0,5\% selama 5, 10 dan 15 menit pada bahan cetak elastomer jenis PVS terdapat adanya perbedaan bermakna stabilitas dimensi cetakan. ${ }^{5}$ Penelitian yang menggunakan desinfektan dengan menggunakan bahan alami juga menunjukkan adanya perubahan stabilitas dimensi bahan cetak. Amelia N (2017) menyatakan adanya perubahan stabilitas dimensi pada cetakan alginat setelah dilakukan penyemprotan dengan ekstrak daun alpukat $100 \%{ }^{22}$

\section{METODE}

Penelitian ini merupakan penelitan eksperimental laboratoris. Sampel pada penelitian ini diperoleh dai hasil pencetakan model induk yang terbuat dari stainless steel berbentuk 2 mahkota yang telah dipreparasi. Sampel dibuat mengikuti ketentuan ADA berukuran diameter (bukolingual) 6,33 mm, tinggi (oklusogingival) 8,02 mm dan jarak antarpreparasi 28,25 mm. Jumlah keseluruhan sampel adalah 30 sampel dan dibagi menjadi 3 kelompok perlakuan, masing-masing berjumlah 10 sampel (Kelompok A: kontrol/tanpa penyemprotan, Kelompok B: penyemprotan dengan ekstrak daun alpukat 25\%, Kelompok C: penyemprotan dengan sodium hipoklorit 0,5\%).

Ekstrak daun alpukat 25\% diperoleh dari 25gram ekstrak kental daun alpukat yang sebelumnya di ekstrak dengan metode maserasi diencerkan dengan akuades hingga mencapai $100 \mathrm{ml}$. Sebelum pencetakan 
dilakukan, terlebih dahulu dilakukan pembuatan sendok cetak fisiologis dari resin akrilik swapolimerisasi dengan stopper di kiri dan kanan sendok cetak. Setelah itu dilakukan pencetakan pada model induk menggunakan sendok cetak fisiologis dengan bahan cetak elastomer jenis polivinil siloksan putty dan light body / wash. Manipulasi bahan cetak polivinil siloksan jenis putty dengan perbandingan base dan katalis 1:1 dan dimanipulasi dengan tangan hingga homogen. Kemudian dilakukan pencetakan pada model induk dengan teknik two step menggunakan spacer sellopan dan tunggu sampai bahan cetak mengeras, spacer sellopan dilepas. Lalu bahan cetak polivinil siloksan wash pasta base dan katalis diaduk di atas glass plate dengan perbandingan 1:1 sampai homogen kemudian dimasukkan ke dalam sendok cetak fisiologis dan dicetak ke model induk. Setelah cetakan mengeras, pada sampel kelompok tanpa penyemprotan (A), cetakan dilepas dan dicuci dengan akuades selama 10 detik kemudian dikeringkan dengan semprotan udara, lalu disimpan dalam plastik yang ditutup rapat (seal bag) selama 10 menit. Untuk sampel kelompok yang disemprot ekstrak daun alpukat 25\% (B), cetakan disemprot dengan $3 \mathrm{ml}$ ekstrak daun alpukat 25\%, lalu disimpan dalam plastik yang ditutup rapat (seal bag) selama 10 menit. Setelah 10 menit, cetakan dibilas dengan akuades lalu dikeringkan dengan semprotan udara. Untuk sampel kelompok yang disemprot larutan sodium hipoklorit (C), cetakan disemprot dengan $3 \mathrm{ml}$ larutan sodium hipoklorit $0,5 \%$, lalu disimpan dalam plastik yang ditutup rapat (seal bag) selama 10 menit. Setelah 10 menit, cetakan dibilas dengan akuades lalu dikeringkan dengan semprotan udara. Cetakan lalu diisi dengan gips keras tipe IV (Fuji Rock) sesuai dengan perbandingan bubuk dan akuades menurut petunjuk pabrik 100 gram : $20 \mathrm{ml}$, pengisian dengan gipsum ini menggunakan vibrator untuk menghindari adanya gelembung udara. Setelah itu hasil cetakan yang telah diisi dibiarkan setting 1-2 jam. Sampel diukur menggunakan kaliper digital. Hasil pengukuran selanjutnya dilakukan perhitungan persentase perubahan stabilitas dimensi. Persentase perubahan stabilitas dimensi dapat dihitung dengan cara melakukan pengukuran model induk dikurang dengan ukuran dimensi model kerja lalu dikali 100 dan dibagi ukuran model induk. Analisis data dilakukan dengan uji Univarian dan uji T tidak berpasangan.

\section{HASIL}

Untuk mengetahui pengaruh penyemprotan ekstrak daun alpukat 25\% pada cetakan elastomer selama 10 menit terhadap stabilitas dimensi, dianalisis dengan uji $\mathrm{T}$ tidak berpasangan. Dari uji t tidak berpasangan dilihat dari bukolingual, oklusogingival dan interpreparasi diperoleh signifikansi $p=0,0001(p<0,05)$, hal ini berarti ada pengaruh penyemprotan ekstrak daun alpukat 25\% pada cetakan elastomer selama 10 menit terhadap stabilitas dimensi (Tabel 1). Persentase perubahan dimensi dibandingkan dengan model induk dilihat dari bukolingual, oklusogingival dan interpreparasi kelompok A adalah 0,039\%, 0,042\% dan 0,021\% dan kelompok B adalah 0,284\%, 0,325\% dan 0,232\% (Tabel 1). Menurut ketentuan spesifikasi ADA no. 19, persentase perubahan dimensi baik dilihat dari bukolingual, oklusogingival dan interpreparasi masih dalam batasan yang dapat ditolerir $(<0,5 \%)$.

Tabel 1. Pengaruh penyemprotan ekstrak daun alpukat 25\% pada cetakan elastomer selama 10 menit terhadap stabilitas dimensi

\begin{tabular}{|c|c|c|c|c|}
\hline \multirow[t]{2}{*}{ Dimensi } & \multicolumn{4}{|c|}{ Stabilitas Dimensi (\%) } \\
\hline & Kelompok & $\mathrm{n}$ & $X \pm \mathrm{sD}$ & $\mathrm{p}$ \\
\hline \multirow[t]{2}{*}{$\begin{array}{c}\text { Buko } \\
\text { Lingual }\end{array}$} & A & 10 & $\begin{array}{ll}0,039 & \pm \\
0,033\end{array}$ & \multirow[t]{2}{*}{$0,0001^{*}$} \\
\hline & B & 10 & $\begin{array}{ll}0,284 & \pm \\
0,060 & \\
\end{array}$ & \\
\hline \multirow[t]{2}{*}{$\begin{array}{c}\text { Okluso } \\
\text { Gingival }\end{array}$} & A & 10 & \begin{tabular}{|l|}
0,042 \\
0,039
\end{tabular} & \multirow[t]{2}{*}{$0,0001^{*}$} \\
\hline & B & 10 & $\begin{array}{ll}0,325 & \pm \\
0,098 & \end{array}$ & \\
\hline \multirow[t]{2}{*}{$\begin{array}{c}\text { Inter } \\
\text { Preparasi }\end{array}$} & A & 10 & \begin{tabular}{|l|}
0,021 \\
0,017 \\
\end{tabular} & \multirow[t]{2}{*}{$0,0001^{*}$} \\
\hline & B & 10 & \begin{tabular}{|l|}
0,232 \\
0,024 \\
\end{tabular} & \\
\hline
\end{tabular}

Ket: * nilai $\mathrm{p}<0,05$, terdapat perbedaan yang signifikan

Untuk mengetahui pengaruh penyemprotan larutan sodium hipoklorit 0,5\% pada cetakan elastomer selama 10 menit terhadap stabilitas dimensi, dianalisis dengan uji $\mathrm{T}$ tidak berpasangan. dari uji $\mathrm{t}$ tidak berpasangan dilihat dari bukolingual, oklusogingival dan interpreparasi diperoleh signifikansi $p=0,0001(\mathrm{p}<0,05)$, hal ini berarti ada pengaruh penyemprotan sodium hipoklorit $0,5 \%$ pada cetakan elastomer selama 10 menit terhadap stabilitas dimensi (Tabel 2). Persentase perubahan stabilitas dimensi dibandingkan dengan model induk dilihat dari bukolingual, oklusogingival dan interpreparasi kelompok A adalah 0,039\%, 0,042\% dan 0,014\% dan kelompok C adalah 0,311\%, 0,350\% dan 0,249\% (Tabel 2). Menurut ketentuan spesifikasi ADA no. 19, persentase perubahan stabilitas dimensi baik dilihat dari bukolingual, oklusogingival dan interpreparasi masih dalam batasan yang dapat ditolerir $(<0,5 \%)$.

Tabel 2. Pengaruh penyemprotan larutan sodium hipoklorit $0,5 \%$ pada cetakan elastomer selama 10 menit terhadap stabilitas dimensi

\begin{tabular}{|c|c|c|c|c|}
\hline \multirow[t]{2}{*}{ Dimensi } & \multicolumn{4}{|c|}{ Stabilitas Dimensi (\%) } \\
\hline & Kelompok & $\mathrm{n}$ & $\bar{X} \pm \mathrm{SD}$ & $\mathrm{p}$ \\
\hline \multirow[t]{2}{*}{$\begin{array}{l}\text { Buko } \\
\text { lingual }\end{array}$} & A & 10 & $\begin{array}{ll}0,039 & \pm \\
0,033\end{array}$ & \multirow[t]{2}{*}{$0,0001^{*}$} \\
\hline & $\mathrm{C}$ & 10 & $\begin{array}{ll}0,311 & \pm \\
0,135\end{array}$ & \\
\hline \multirow[t]{2}{*}{$\begin{array}{l}\text { Okluso } \\
\text { gingival }\end{array}$} & A & 10 & $\begin{array}{l}0,042 \\
0,039\end{array}$ & \multirow[t]{2}{*}{$0,0001^{*}$} \\
\hline & $\mathrm{C}$ & 10 & $\begin{array}{l}0,350 \\
0,166\end{array}$ & \\
\hline \multirow[t]{2}{*}{$\begin{array}{c}\text { Inter } \\
\text { preparasi }\end{array}$} & A & 10 & $\begin{array}{ll}0,021 & \pm \\
0,017 & \end{array}$ & \multirow[t]{2}{*}{$0,0001^{*}$} \\
\hline & $\mathrm{C}$ & 10 & $\begin{array}{ll}0,249 \\
0,107\end{array}$ & \\
\hline
\end{tabular}


Ket: * nilai $\mathrm{p}<0,05$, terdapat perbedaan yang signifikan

Untuk mengetahui perbedaan pengaruh antara penyemprotan ekstrak daun alpukat 25\% dan larutan sodium hipoklorit 0,5\% pada cetakan elastomer selama 10 menit terhadap stabilitas dimensi, dianalisis dengan uji $\mathrm{T}$ tidak berpasangan. Dari uji t tidak berpasangan, tidak ada perbedaan pengaruh penyemprotan cetakan elastomer dengan ekstrak daun alpukat 25\% dan larutan sodium hipoklorit $0,5 \%$ pada cetakan elastomer selama 10 menit terhadap stabilitas dimensi dilihat dari bukolingual diperoleh $p=0,366(p>0,05)$, dilihat dari oklusogingival diperoleh $\mathrm{p}=0,615(\mathrm{p}>0,05)$, dan dilihat dari interpreparasi diperoleh $p=0,079(p>0,05)$ (Tabel 3).

Tabel 3. Perbedaan pengaruh penyemprotan ekstrak daun alpukat 25\% dan larutan sodium hipoklorit 0,5\% pada cetakan elastomer selama 10 menit terhadap stabilitas dimensi

\begin{tabular}{|c|c|c|c|c|}
\hline \multirow[t]{2}{*}{ Dimensi } & \multicolumn{4}{|c|}{ Stabilitas Dimensi (\%) } \\
\hline & Kelompok & $n$ & $\overline{\bar{X}} \pm \mathrm{SD}$ & $\mathrm{p}$ \\
\hline \multirow[t]{2}{*}{$\begin{array}{c}\text { Buko } \\
\text { Lingual }\end{array}$} & B & 10 & $\begin{array}{ll}0,284 & \pm \\
0,060 & \end{array}$ & \multirow[t]{2}{*}{0,366} \\
\hline & $\mathrm{C}$ & 10 & $\begin{array}{ll}0,311 \quad \pm \\
0,135\end{array}$ & \\
\hline \multirow[t]{2}{*}{$\begin{array}{c}\text { Okluso } \\
\text { Gingival }\end{array}$} & B & 10 & $\begin{array}{ll}0,325 & \pm \\
0,098 & \end{array}$ & \multirow[t]{2}{*}{0,615} \\
\hline & $\mathrm{C}$ & 10 & $\begin{array}{ll}0,350 & \pm \\
0,166 & \end{array}$ & \\
\hline \multirow[t]{2}{*}{$\begin{array}{c}\text { Inter } \\
\text { Preparasi }\end{array}$} & B & 10 & $\begin{array}{l}0,232 \quad \pm \\
0,024\end{array}$ & \multirow[t]{2}{*}{0,079} \\
\hline & $\mathrm{C}$ & 10 & $\begin{array}{ll}0,249 & \pm \\
0,107 & \end{array}$ & \\
\hline
\end{tabular}

Tidak ada perbedaan yang signifikan $(\mathrm{p}>0,05)$

\section{PEMBAHASAN}

Stabilitas dimensi model pada kelompok A, B, dan $\mathrm{C}$ menunjukkan bahwa nilai persentase perubahan stabilitas dimensi kelompok A lebih kecil dibandingkan kelompok lain sedangkan nilai perubahan stabilitas dimensi kelompok C lebih besar dibandingkan dengan kelompok lain baik diukur dari bukolingual, oklusogingival maupun interpreparasi. Perbedaan ini kemungkinan disebabkan karena pada kelompok kontrol hanya dibilas menggunakan akuades, sehingga dimensi pada hasil cetakan tidak mengalami perubahan yang terlalu besar.

Pada tabel 1 dan tabel 2, hasil uji $\mathrm{T}$ tidak berpasangan menunjukkan ada pengaruh yang signifikan pada penyemprotan ekstrak daun alpukat 25\% dan sodium hipoklorit pada cetakan elastomer selama 10 menit terhadap stabilitas dimensi, hal ini terlihat dari ukuran dimensi model kerja yang lebih kecil. Hal ini dapat disebabkan karena bahan cetak PVS yang hidrofilik cenderung mempunyai wettability yang tinggi. Ongo TA (2014) menyatakan sifat wettability yang tinggi membuat bahan cetak tersebut menyerap larutan desinfektan sehingga menjadikannya lebih mudah untuk mengalami perubahan stabilitas dimensi apabila didesinfeksi. Sifat wettability pada bahan cetak yang bersifat hidrofilik akan menyerap air saat didesinfeksi dengan desinfektan dan akan mengalami ekspansi ke segala arah baik bukolingual, oklusogingival, maupun interpreparasi. ${ }^{5}$ Hal ini sesuai dengan pernyataan Milward dkk (2001) bahwa bahan desinfektan dapat mempengaruhi wettability bahan cetak PVS. $^{23}$ Lamanya cairan desinfeksi kontak dengan hasil cetakan setelah didesinfeksi juga kemungkinan dapat menyebabkan perubahan stabilitas dimensi. ${ }^{5}$ Selain itu, perubahan stabilitas dimensi kemungkinan juga dapat disebabkan karena adanya pembilasan kembali hasil cetakan PVS dengan akuades setelah dilakukan proses desinfeksi sehingga semakin meningkatkan kuantitas cairan yang diserap. Proses elastic recovery yang tidak sesuai sebelum hasil cetakan diisi dengan gips juga kemungkinan menyebabkan adanya perubahan stabilitas dimensi pada hasil cetakan, dalam hal ini untuk bahan cetak PVS membutuhkan elastic recovery selama 30 menit sebelum pengisian hasil cetakan dengan gips. ${ }^{24}$ Perubahan stabilitas dimensi pada kelompok B tidak jauh berbeda dengan kelompok A karena adanya kandungan fenol dalam ekstrak daun alpukat, dimana dalam hal komposisi larutan desinfektan fenol dapat menguap sehingga ekstrak daun alpukat yang diserap bahan cetak berkurang. ${ }^{25}$ Perubahan stabilitas dimensi pada kelompok C lebih besar dibandingkan dengan kelompok A dan B dapat disebabkan tidak adanya kandungan sodium fosfat pada bahan cetak PVS seperti bahan cetak lain contohnya alginat. Sodium hipoklorit mampu berikatan dengan kandungan sodium fosfat sehingga meminimalisir penyerapan cairan oleh bahan cetak. Dikarenakan hal tersebut penyerapan sodium hipoklorit pada bahan cetak PVS jauh lebih besar. Faktor lainnya adalah konsentrasi cairan sodium hipoklorit yang kecil hanya 5\% juga kemungkinan dapat mempengaruhi penyerapan terhadap sodium hipoklorit hal ini sesuai dengan pernyataan Parimata (2014) yang menyatakan bahwa pengaruh desinfektan terhadap bahan cetak juga tergantung dari jenis dan konsentrasi desinfektan tersebut. ${ }^{26}$ Menurut spesifikasi ADA No. 19, presentase perubahan stabilitas dimensi semua kelompok baik diukur dari bukolingual, oklusogingival, dan interpreparasi masih dalam batas yang dapat ditolerir $(<0,5 \%){ }^{21}$

Persentase perubahan stabilitas dimensi dibandingkan kelompok A dengan kelompok B serta dibandingkan kelompok A dengan kelompok C menunjukkan dimensi model mengecil disebabkan karena terjadinya ekspansi bahan cetak tidak diimbangi dengan setting ekspansi dari gips itu sendiri, dimana ekspansi gipsum berupa perubahan hemihidrat menjadi dihidrat saat setting. Pada proses ini terjadi mekanisme kristalisasi, yaitu pertumbuhan berlebihan dari kristal-kristal nukleus kristalisasi. Berdasarkan keterkaitan kristal-kristal dihidrat, kristal tumbuh dari nuklei dapat berikatan ataupun menghalangi pertumbuhan kristal yang berdekatan. Bila proses ini diulangi oleh ribuan kristal selama pertumbuhan, suatu tekanan atau dorongan keluar dapat terjadi yang menghasilkan ekspansi pada model kerja. ${ }^{27}$ Ekspansi dari bahan cetak PVS yaitu berupa model yang mengecil jika tidak diimbangi dengan setting ekspansi dari gipsum menyebabkan ukuran model kerja lebih kecil dari model induk, walaupun persentase perubahan stabilitas 
dimensinya masih bisa ditolerir.Pada tabel 3 diperoleh tidak ada ada perbedaan pengaruh antara penyemprotan cetakan elastomer selama 10 menit dengan ekstrak daun alpukat 25\% dan larutan sodium hipoklorit 0,5\% terhadap stabilitas dimensi. Menurut Merchant dkk (2004) dan Ongko DP (2012) larutan sodium hipoklorit 0,5\% dapat digunakan untuk mendesinfeksi bahan cetak karena mengandung senyawa klorin yang tergolong golongan halogen (intermediate level disinfectant). ${ }^{5}$ Katja dkk (2009) menyatakan bahwa daun alpukat mengandung flavonoid, alkaloid, polifenol, tanin dan saponin. Flavonoid, alkaloid, dan saponin termasuk senyawa fenol, yang mempunyai aktivitas antibakteri dan mampu menghambat pertumbuhan bakteri, sehingga dapat digunakan sebagai desinfektan. $^{17}$ Walaupun tidak terdapat perbedaan pengaruh antara penyemprotan cetakan elastomer selama 10 menit dengan ekstrak daun alpukat 25\% dan larutan sodium hipoklorit $0,5 \%$ terhadap stabilitas dimensi, namun terlihat perbedaan persentase perubahan stabilitas dimensi antara kedua kelompok. Hal ini mungkin disebabkan ekstrak daun alpukat mengandung fenol, dimana dalam hal komposisi larutan desinfektan fenol dapat menguap sehingga ekstrak daun alpukat yang diserap bahan cetak berkurang. Berkurangnya ekstrak daun alpukat 25\% yang diserap bahan cetak menyebabkan kelompok B (ekstrak daun alpukat 25\%) mempunyai nilai persentase perubahan stabilitas dimensi yang lebih kecil dibandingkan kelompok C (larutan sodium hipoklorit 0,5\%). Hasil penelitian ini menunjukkan bahwa penggunaan ekstrak daun alpukat dapat dijadikan desinfektan cetakan elastomer karena perubahan dimensi yang terjadi lebih kecil dibandingkan larutan sodium hipoklorit 0,5\%.

Dari hasil penelitian ini dapat disimpulkan bahwa ada perubahan stabilitas dimensi yang terjadi tetapi masih dalam batas yang dapat ditolerir $(<0,5 \%)$ pada cetakan elastomer yang dilakukan desinfeksi dengan penyemprotan ekstrak daun alpukat 25\% maupun larutan sodium hipoklorit $0,5 \%$ sehingga keduanya bisa digunakan sebagai alternatif bahan desinfeksi untuk bahan cetak elastomer.

\section{DAFTAR PUSTAKA}

1. Rahmayani L, Herwanda, Idawani M. Perilaku pemakai gigi tiruan terhadap pemeliharaan kebersihan gigi tiruan lepasan. Jurnal PDGI 2013; 62(3): 83-8.

2. Vitti RP, Silva MABd, Consani RLX, Sinhoreti MAC. Dimensional accuracy of stone casts made from silicone-based impression materials and three impression techniques. Brazilian dental journal 2013; 24(5): 498-502.

3. FauesSria ACL, Silveira CS, Rodrigues S, dkk. Accuracyof stone casts obtained by different impression materials. Braz Oral Res 2008; 22(4): 293-8.

4. Nallaswamy D. Textbook of Prosthodontics. New Delhi: Jaypee, 2003: 80, 809.

5. Ongo TA, Rachmadi P, Arya IW. Stabilitas dimensi hasil cetakan bahan cetak elastomer setelah disemprot menggunakan sodium hipoklorit. Dentino J Ked Gigi 2014; 2(1): 83-8.

6. Leao MP, Pinto CP, dkk. Dimensional stability of a novel polyvinyl siloxane impression technique. BJOS 2014; 13(2): 118-23.

7. Ramakrishnaiah R, Kheraif AAAA, Qasim SSB. The effect of chemical desinfection, autoclave, microwave sterilization on the dimensional accuracy of polyvinyl siloxane elastomeric impression materials. World App Sci J 2012; 17(1): 127-32.

8. Lu H, Nguyen B, Powers JM. Mechanical properties of 3 hydrophilic addition silicone and polyether elastomeric impression materials. J Prosthet Dent 2004; 92: 151-4.

9. Sari DF, Parnaadji RR, Sumono A. Pengaruh teknik desinfeksi dengan berbagai macam larutan desinfektan pada hasil cetakan alginate terhadap stabilitas dimensional. Jurnal Pustaka Kesehatan 2013;1(1):29-34.

10. Silva SMLM, Salvador MCG. Effect of the desinfection technique on the linear dimensional stability of dental impression materials. J ApplSci 2004; 12(3): 244-9.

11. Badrian H, Ghasemi E, Khalighinejad N, Hosseini $\mathrm{N}$. The effect of three different disinfection materials on alginate impression by spray method. ISRN Dentistry 2012; 1-5.

12. Ghahramanloo A, Sadeghian A, Sohrabi K, Bidi A. A microbiologic investigation following the disinfection of irreversible hydrocolloid materials using the spray method. CDA journal 2009; 37(7): 471-7.

13. Sedky NA. Evaluation of practice of cross infection control for dental impressions among laboratory technicians and prosthodontists in KSA. International journal of infection control 2014; 10(3): 2-12.

14. Hiraguchi H, Kaketani M, Hirose H, Yoneyama T. Effect of immersion disinfection of alginate impressions in sodium hypochlorite solution on the dimensional changes of stone models. Dental Materials Journal 2012; 31(2): 280-6.

15. Santosh D, Raghunath AP, Gangadhar SA. Efficacy of various spray disinfectants on irreversible hydrocolloid impression materials: an in vitro study. Indian Journal Dentistry Res 2011; 22(6): 764-9.

16. Chayadie FL, Adi S, Sari RP. Daya hambat ekstrak daun alpukat (Persea americana mill) terhadap pertumbuhan Enterococcus faecalis. Denta Jurnal Kedokteran Gigi 2014; 8(1): 1-10.

17. Katja DG, Suryanto E, Wehantouw F. Potensi daun alpukat (Persea americana mill) sebagai sumber antioksidan alami. Chem. Prog. 2009; 2(1): 58-64.

18. Fauzia, Larasati A. Uji efek ekstrak air dari daun avokad (perseagratissima) terhadap Streptococcus mutans dari saliva dengan kromatografi lapisan tipis (TLC) dan konsentrasi hambat minimum 
(MIC). Majalah Kedokteran Indonesia. 2008; 41(3): 173-7.

19. Zeni MA, Kristiana D, Fatmawati DWA. Pengaruh air rebusan daun salam (Eugenia polyanthawight) $100 \%$ dan sodium hipoklorit (NaOCl) $1 \%$ sebagai desinfektan terhadap stabilitas dimensi hasil cetakan alginat. Stomatognatic (J. K. G Unej) 2014; 11(1): 12-15.

20. Melili D, Rallo A, Cassaro A. The effect of immersion disinfection procedures on dimensional stability of two elastomeric impression materials. Journal of Oral Science 2008;50(4): 441-46.

21. Saber FS, Abolfazli N, Kohsoltani M. The effect of disinfection by spray atomization on dimensional accuracy of condensation silicone impressions JODDD. 2010; 4(4): 124-9.

22. Amelia N. Perbedaan stabilitas dimensi antara cetakan alginat yang diberi desinfektan ekstrak daun alpukat (Persea Americana mill) dengan natrium hipoklorit. Skripsi. Padang: Fakultas Kedokteran Gigi Universitas Andalas; 2017.

23. Febriani M, Herda E. Pemakaian desinfektan pada bahan cetak elastomer. JITEKGI 2009; 6(2): 4144.

24. Power JM, Sakaguchi RL. Craig's: restorative dental material. Ed 13th St Louis: Elsevier, 2012: 289 .

25. Devina S. Pengaruh penyemprotan Daun sirih dan sodium hipoklorit pada cetakan elastomer terhadap perubahan dimensi. Jurnal Material Kedokteran Gigi. 2016; 3(5): 36-44.

26. Parimata VN, Rachmadi P, Arya IW. Stabilitas dimensi hasil cetakan alginate setelah dilakukan penyemprotan infusa daun sirih merah (Piper crocatum Ruiz \& Pav) 50\% sebagai desinfektan. Dentino J Ked Gigi 2014; 2(1): 74-78.

27. Anusavice KJ. Phillips buku ajar ilmu bahan kedokteran gigi (Phillips' sciences of dental materials). Alih bahasa. Budiman JA, Purwoko S. Edisi 10. Jakarta: EGC, 2004: 163,164. 